\title{
Employee Rosters Rise; Wages Continue To Climb
}

\author{
A.S. Leaflet R2167 \\ James Kliebenstein, Professor, Iowa State University, \\ Terrance Hurley, Associate Professor, University of \\ Minnesota, \\ Peter Orazem, Professor, Iowa State University, \\ Dale Miller, editor, National Hog Farmer, and \\ Steve May, publisher, National Hog Farmer
}

\section{Summary and Implications}

A survey of pig producers and employees was conducted to document trends in the industry. These surveys have been conducted four times: 1990, 1995, 2000, and 2005. Trends show that pig production operation sizes are increasing leading to an increase in the number of employees. Between 1990 and 2005 the average number of full-time employees per operation increased from 2.9 to 8.8; an increase of 20.3 percent.

The wages of employees rose between 1990 and 2005 and wage discrepancies widened also. The average wage in the pork industry increased from $\$ 19,847$ in 1990 to $\$ 35,718$ in 2005 , an 80 percent increase. The average wage increased by 23.5 percent between 1990 and 1995 by 26.1 percent between 1995 and 2000, and by 15.4 percent between 2000 and 2001. The average civilian wage increased by about 61 percent during the 1990-2005 time period. While the average wage growth over the past 15 years is good news for the industry employees, wage growth in the industry between 2000 and 2005 is not as encouraging; 15.4 percent for pork industry employees versus 21.2 percent for the average civilian worker. The industry has lost some of the wage gains it had during the 1990s.

Men in the pork sector have enjoyed higher wages than women while wage growth was greater for women over the 1990-2005 time period. However, during the 2000-2005 time period wage growth for women dipped below that for men. Employees with a four-year college degree had a stronger than average wage growth. Wage growth for employees with a two-year college degree or less grew at a rate below the industry average.

Between 2000 and 2005 the pay scale for managers was the highest (average of $\$ 38,060$ ), followed by assistant managers (average of $\$ 33,115$ ), then farrowing managers (average of \$30,780), and herdsmen (average of $\$ 29,400$ ).

The percent of employees receiving bonuses and incentive pay declined from 57.4 percent in 2000 to 54.8 percent in 2005 . There was a decline in the percent of employees receiving pig death loss bonuses. Benefits received by employees appear to be stable to declining during the 2000-2005 time period. A growth area of benefits has been in the pension and retirement benefit area.

\section{Introduction}

The pig production industry is experiencing changes in employment trends. As firms grow the need for employees grows as well. To document some of the changes a survey was conducted in late 2004 (2005 survey) of pig production employees and employers. This is the fourth survey in a 15 year span. The goal of the survey was to track changes in the employment market for pig production. Results of the 2005 survey are compared to the previous three surveys conducted in five year intervals $(2000,1995$, and 19990). This report documents in wage levels, factors affecting wages, along with incentives and benefits received by employees.

\section{Materials and Methods}

As indicated, this was the fourth survey in a 15 year span. A mail questionnaire was sent to pork producers and employees across the United States. Select questions in both surveys overlapped so that responses could be compared in key areas.

The National Hog Farmer qualified mailing list provided a select sample of producers/owners. A random sample of producers with an annual production of 3,000 head or more, or verified with 100 sows or more, were surveyed. All employees on the National Hog Farmer list were sent the survey.

Responses were tabulated to identify averages and differences. Not everyone answered every question, so the number of respondents may vary slightly with each question.

Iowa State University and University of Minnesota economists teamed with National Hog Farmer and Pfizer Animal Health to conduct the study.

\section{Results and Discussion}

As the average size of pork production unit's increased and multiple-site production gained in popularity, the number of full-time employees edged upward. The percentage of producers who had two or fewer employees has fallen significantly since 1990 (Table 1). In 1990, almost three in four $(71.7 \%)$ had two or fewer employees. This remained at $72 \%$ in 1995 and declined to $56.1 \%$ and $55.3 \%$ in 2000 and 2005. Not much change was evident from 2000 to 2005. The percentage of producers who 
reported that they had nine or more employees increased dramatically. This increased from $3.6 \%$ in 1990 to $13.4 \%$ in 2005 . The major shift occurred between 1995 and 2000. In 1995 4.9\% of the producers had nine or more employees. This had increased to $12.2 \%$ by 2000 . Growth in the number of employees for the larger operations has reached a plateau during the 2000s. However, growth in operations which is the largest, those which hire more than 50 employees continues. It represented $0.3 \%$ in $1990,0.8 \%$ in $1995,2.0 \%$ in 2000 and currently represents $3.6 \%$ of the employees.

The increase in the average number of full-time employees further demonstrates this trend. Between 1990 and 2000, the average number of full-time employees increased by $179 \%$ from 2.9 to 8.1 . It increased to 8.8 , another $8.6 \%$ by 2005 . Larger staffs translate to an increased demand for employees. This greater demand puts added pressure on employers to offer competitive salaries, incentives and fringe benefits. Larger staffs also require greater people skills and better employer-employee communications.

\section{Distribution of Wages}

The wages of employees rose between 1990 and 2005 and wage discrepancies widened. A general increase in employee wages between 1990 and 1995 was equitably distributed. But, between 1995 and 2000, the general increase continued and the wage disparity grew wider. This grew even wider between 2000 and 2005. Almost two-thirds (64.2\%) of employees earned between $\$ 10,000$ and $\$ 25,000$ in 1990 , and between $\$ 15,000$ and $\$ 30,000$ in 1995 (Table 2). In 2000, 56.2\% of employees earned between $\$ 20,000$ and $\$ 35,000$. This was $45.1 \%$ in 2005. The percentage of employees reporting wages below these ranges was 14.1 in 1990, 12.9 in 1995, 15.2 in 2000, and $12.3 \%$ in 2005 . Those earning $\$ 10,000$ or less increased from $3.3 \%$ in 2000 to $5.9 \%$ in 2005; back to the approximate level of 1995 . Those reporting wages above $\$ 40,000$ represented $3.5 \%$ in 1990 . This percentage has doubled every five years. It increased to $7.2 \%$ in $1995,15.3 \%$ in 2000 and $30.3 \%$, or about one in three employees in 2005. The percent earning more than $\$ 60,000$ more than doubled from 2000 to 2005, an increase from $4.0 \%$ to $9.3 \%$. Approximately one in seventeen employees $(5.7 \%)$ received more than $\$ 75,000$ of base salary in 2005 .

\section{Factors Affecting Wages}

Level of education, gender, experience, job tenure, employer size and regional location affected wage rates. To better understand the impact of these factors on wages, statistical techniques can be used to compare the average wages of employees that differ only by the factor of interest, such as gender.

Table 3 shows how various factors affect wages using these statistical comparisons. For example, the difference in wages for a woman versus man in 2005 was $27.3 \%$. In other words, a woman with the same education, experience, and tenure working in the same type of operation as a man earned $27.3 \%$ less on average.

In 1990, a woman earned $32.4 \%$ less on average than a man did. In 1995, women still earned less than men, but the difference narrowed. By 2000, women's wages were more equal to men when compared to 1990, but the gap between 1995 and 2000 widened again. The gap widened still further between 2000 and 2005 .

The differences in wages across employees in the pork industry are consistent with findings in other industries. In the labor market as a whole, women earn less than men. For civilian workers in 2002, U.S. Census Bureau data indicate $38.5 \%$ less. Employees with more education, tenure, and experience earn more. Employees working for operations with more full-time employees or higher levels of production also earn more.

Another example, the difference in wages for a high school graduate versus high school dropout was $9.9 \%$ in 2005 . This comparison assumes the same gender, same amount of experience and tenure and same size of operation in the same region. The only difference is a high school diploma.

However, the wage advantage for high school graduates versus dropouts was actually less in 2005 $(9.9 \%)$ than in either $2000(15 \%), 1995(19.0 \%)$, or $1990(24.5 \%)$. The value for having a two-year college degree versus a high school diploma increased from $8.9 \%$ to $12.5 \%$ from 1995 to 2005 . The increase in wages from having a four-year versus two-year college degree grew from $10.7 \%$ in 2000 to $21.8 \%$ in 2005 , returning back to the level it was in 1990. When compared to high school graduates, the increase in wages from obtaining a four-year college degree grew from $23.1 \%$ to $34.4 \%$ between 2000 and 2005.

As experience and tenure increase by one year, the value in wages increased by $1.9 \%$ in 2005 . This was in the $1-2 \%$ range over the $1990-2005$ time period. The increase in wages from one more year of tenure for an employee with average tenure was $0.8 \%$ in 2005 , which reflects and increase from $0.2 \%$ in 2000.

For each additional 10 full-time employees hired by an operation, an employee's wages increased very little in 2005. This impact has declined over time. In 2005, employees working for operations producing between 5,000 and 10,000 hogs annually could have 
earned $32.4 \%$ more if they had worked in an operation producing more than 10,000 hogs annually on average. This difference has increased compared to either $1990(13.6 \%), 1995(14.3 \%)$, or 2000 $(21.1 \%)$.

On average, an employee working for an operation that produced over 10,000 hogs annually would have earned $55 \%$ more in $1990,35.9 \%$ more in $1995,12.3 \%$ more in 2000 , and $20.2 \%$ more in 2005 if he or she were to switch to a less than 1,000 head operation.

In 2005, the average worker in the Midwest would have earned $8.9 \%$ more in an identical operation in the Northeast, $2.6 \%$ more in the Southeast and $8.9 \%$ less in the West. The increase in wages in the Northeast brings them back to a level similar to what they were in 1990 (11.8\%). In 2000 they were $4.1 \%$ under Midwest wages. In 2005, wages in the southeast were $2.6 \%$ above Midwest wages as compared to $7.2 \%$ greater in 2000 . Wages in the Southeast have become more similar to Midwest wages.

\section{Wages and Wage Growth}

In the first pork industry employment survey conducted 15 years ago (1990), the average wage in the pork industry was substantially less than that of the average civilian worker in the U.S. But, due to strong wage growth between 1990 and 2005, the average wage paid pork production employees is now almost comparable to the average wage of civilian workers.

The average wage in the pork industry increased by $23.5 \%$ from $\$ 19,847$ to $\$ 24,515$ between 1990 and 1995 , by another $26.1 \%$ to $\$ 30,959$ in 2000 , and to $\$ 35,718$ in 2005 , another 15.4 percent (Table 4$)$. The total increase was almost $80 \%$ in just under 15 years. During this same period, the average civilian wage, as measured by the Bureau of Labor Statistics Employment Cost Index (EIC), increased by only $60.8 \%$. While stronger than average wage growth over the past 15 years is certainly good news for industry employees, wage growth in the industry between 2000 and 2005 was not as strong: $15.4 \%$ for pork industry employees versus $21.2 \%$ for the average civilian worker.

In 1990, the average civilian worker in the U.S. earned about $\$ 23,074$, which was $16 \%$ higher than average earnings in the pork industry. Based on EIC data, this annual earning increased to about $\$ 37,097$ in 2005 , which is $3.9 \%$ higher than average pork industry earnings. Again, while the 15 year trend is certainly good news, the industry has lost ground since 2000 when civilian labor force earnings were only $3 \%$ higher than pork industry earnings.

\section{Wages by Gender}

Men in the pork sector have enjoyed stronger than average wage growth, attributed to high education levels, working for larger operations and having more experience. Women in the pork sector enjoyed stronger wage growth than men. Between 1990 and 2005, average earnings for men grew by $82.4 \%$ from $\$ 20,123$ to $\$ 36,712$, while average earnings for women grew by $85.4 \%$ from $\$ 15,300$ to $\$ 28,364$. However, in the past five years, wage growth for men has been stronger than for women: $15.9 \%$ versus $12.8 \%$.

\section{Wages by Education}

Employees with a four-year college degree had stronger than average wage growth. It grew by $21.3 \%$ from 2000 to 2005 . While high school dropouts, high school graduates, and two-year college graduates also saw wages grow, the growth was less than the industry average. The growth rate from 2000 to 2005 was only about half that of fouryear college graduates. Between 1990 and 2005, employees with a two-year college degree had an $81.8 \%$ increase in wages from $\$ 19,105$ to $\$ 34,735$.

Wages for employees with a high school diploma grew by $70.8 \%$ from $\$ 17,991$ to $\$ 30,727$, while those with a four-year college degree increased $74.4 \%$ from $\$ 24,242$ to $\$ 42,279$. High school dropouts enjoyed an $86.6 \%$ increase from $\$ 14,301$ to $\$ 26,679$.

However, their wages only increased by $8.4 \%$ between 2000 and 2005 for high school dropouts, which was the lowest growth rate of all the different groups.

\section{Wages by Annual Production}

Comparing wages by annual hog production in the 2005 survey shows a vast disparity. Those producing 2,000 or fewer hogs had higher wages than those producing in the 2,000 to 10,000 range. This may be, in part, related to increases from other enterprises for the smaller operation. It may also be related to specialty or niche markets. The average earnings of employees in operations producing more than 10,000 hogs annually were more than $\$ 11,000$ higher than those producing between 5,000 and 10,000 and about $\$ 9,500$ higher than those producing 3,000 to 5,000.

Part of this disparity is attributed to the fact that employees working in 10,000-plus operations typically have more education. But even without more education, Table 4 shows these employees would have still earned substantially more. If this disparity remains, medium sized operations may find it difficult to attract and retain quality employees.

Fifteen-year wage growth was strongest for employees working in operations producing fewer 
than 1,000 hogs annually. Their wages increased $120 \%$ from $\$ 14,811$ to $\$ 32,639$. Employees in operations producing 1,000-2,000 saw an increase of $100 \%$ from $\$ 17,078$ to $\$ 34,148$, while those in operations producing 2,000-3,000 increased 33.5\% from $\$ 18,435$ to $\$ 24,612$. Wages increased by $48.8 \%$ from $\$ 19,328$ to $\$ 28,752$ in operations producing 3,000-5,000 and $27 \%$ from $\$ 20,931$ to $\$ 26,608$ in operations producing 5,000-10,000. In units with 10,000-plus annual production, wages increased from $\$ 26,124$ to $\$ 38,157$ or $46 \%$.

\section{Regional Wages}

Wage growth in the Midwest exceeded the average, primarily because education levels rose, as did the size of operations.

In 1990, average wages were highest in the Southeast $(\$ 23,402)$, followed by the West $(\$ 21,385)$, Northeast $(\$ 19,502)$ and Midwest $(\$ 19,098)$. Wage growth shifted between 1990 and 2005, with the strongest growth in the Midwest $(86 \%)$ followed by the Northeast (77\%), Southeast (70\%) and West $(61 \%)$. More recent trends in wage growth $(2000$ to 2005) favor employees in the Northeast (23.1\%) followed by the Midwest (17.1\%), Southeast (11.7\%), and West (9.3\%).

\section{Wages by Job Title}

The wage disparity between assistant managers and herdsmen relative to managers has widened. The disparity between manager and farrowing manager remains. An increase in the percentage of women placed as farrowing managers and a decline in the number with four-year College degrees are cited as factors.

The average wages of managers have consistently been higher than those of assistant managers, farrowing managers, and herdsmen. In 1990 and 1995, farrowing managers were the next highest paid employees followed by assistant managers and herdsmen. In 2000 and 2005, assistant managers ranked second for pay, followed by farrowing managers and herdsmen. Wage growth between 1990 and 2005 was highest for assistant managers $(81.8 \%)$, and managers $(81.4 \%)$, followed by herdsmen $(67.3 \%)$, and farrowing managers $(65.7 \%)$. The current five year trend in wage growth favors managers with a $17.9 \%$ increase followed by assistant managers (9.7\%), farrowing managers (8.8\%), and Barn Workers/Herdsmen (5.8\%).

\section{Incentive Plans}

Bonus and incentive plans can serve to augment employee wages' and make it easier to attract and retain quality employees. The percentage of producers and employees that reported bonuses and incentive pay between 1990 and 2000 increased. However, between 2000 and 2005 this percentage declined.

The percent of employees receiving bonuses and incentive pay declined from $57.9 \%$ in 2000 to $54.8 \%$ in 2005 and was lower than the level in 1995 (Table 5). Much of this decrease appears attributable to fewer employees receiving pig death loss bonuses. The primary bonus/incentive was pig death loss. In $2000,57.9 \%$ of the employees received this bonus. This compared to $54.8 \%$ in 2005 . There was a slight increase in number of employees who received bonuses based on pigs per crate per year between 2000 and 2005. Feed efficiency became less of a factor in determining bonuses in 2005; the reduction was $26 \%$. Producers also indicated that fewer were offering bonuses in 2005 than 2000. It had declined to only $38.1 \%$ offering bonuses and incentive pay. They too reported relying more on pigs per crate per year and less on feed efficiency. Death loss was the primary factor reported for determining bonuses and incentives.

\section{Benefits Offered}

The trend toward providing benefits to employees is mixed, at least when they answered the questions. Employees reporting that their employer provided medical, dental, disability and life insurance coverage fell in 1995, in 2000, and again in 2005 (Table 6). Conversely, up until 2000 a larger percentage of employees reported receiving paid vacation, paid holidays, workers compensation, unemployment insurance, paid sick leave and pension or retirement plans. During this time, the decline in disability insurance was accompanied by an increase in employers providing workers' compensation.

Between 1990 and 2005, 17.5\% fewer employees reported receiving medical insurance, and dental coverage fell by $23.9 \%$. The number of employees receiving disability insurance declined $56.9 \%$, and the number receiving life insurance declined $47 \%$. The biggest drop occurred between 1995 and 2000 but the erosion of benefits continued into 2005. This decline in medical coverage is troubling because good health care is important and costly.

Between 1995 and 2000, the employee's average share of medical insurance premiums fell from $55.4 \%$ to $17.1 \%$. This share increased to $26.2 \%$ in 2005 . The employee's share of dental insurance premiums likewise fell, from $72.4 \%$ to $34.4 \%$ between 1995 and 2000 , but increased to $40.6 \%$ in 2005 . Similarly, their share of disability insurance premiums fell from $77.4 \%$ to $21.3 \%$ between 1995 and 2000 before increasing to $33.4 \%$ in 2005 , and their share of life insurance premiums fell from $82.6 \%$ to $18.4 \%$ 
between 1995 and 2000 before increasing to $25.0 \%$ in 2005.

Paid vacation was received by the most employees. However, this too declined from 2000 to 2005 ; a decline of $16 \%$ over the five year period. Fewer employees are receiving paid holidays and paid sick leave. For paid holidays this decreased by 16 percent from 2000 to 2005 . The decrease for paid sick leave was $26.5 \%$. There was also a $17.7 \%$ decline in workers compensation, $25.4 \%$ decline in profit-sharing plan, and a $30.1 \%$ decline in housing provided. Between 1990 and 2005, the average number of vacation days increased from 10.7 to 13.2 days, which reversed the previous downward trend. The average number of sick days fell from 7.6 to 6.3 between 1990 and 2005, but has increased from a low of 6.0 in 2000. The average number of holidays remained stable (six days).

The percentage of employees that received workers compensation increased $22.1 \%$ between 1990 and 2000. This declined to only about one-half the workers in 2005 , a decline of about $18 \%$.

More employees are receiving pension and retirement plans. In 1995, 35.7\% indicated receiving a pension or retirement plan. In 2000, the percentage rose to $49.7 \%$; a $39.2 \%$ increase. This increased another $8.9 \%$ from 2000 to 2005 . The increased use of pensions and retirement plans is a natural strategy to counteract the increased mobility of the labor force. Because pension contributions need not be fully vested until the employee has been with the firm for five years, pension plans serve to increase the incentive for the worker to stay. Incentive plans also serve to tie the workers' incentives more closely to farm productivity and profitability in a climate in which fewer workers plan to graduate to ownership or management positions.

Employees typically received fewer in-kind benefits in 2000 when compared to 1990 . More than $40 \%$ received housing in 1990, compared to about $30 \%$ in 2000; and $21 \%$ in 2005. Almost 30\% received paid utilities in 1990, but less than $15 \%$ did in 2005. There was a slight increase in employees receiving a company vehicle $(21.3 \%)$, and almost $45 \%$ received processed meat in 2005 , a slight increase from 2000. About $20 \%$ received continuing education expenses in 2005, about the same as in 1990.

Comparing benefits by the size of operation reveals an important trend. Larger operations offer more generous benefits packages. The only exception to this observation is the provision of housing and utilities. With higher wages and more generous benefits packages, larger operations will find it easier to attract and retain employees.

Producers/employers also were polled on the medical and dental benefits, life insurance and disability insurance offered to employees. Their responses reflected the general trends employees reported here.

\section{Acknowledgements}

Appreciation is expressed to the National Pork Board for providing funding for the study. 
Table 1: Number of Full-Time Employees Reported by Producers.

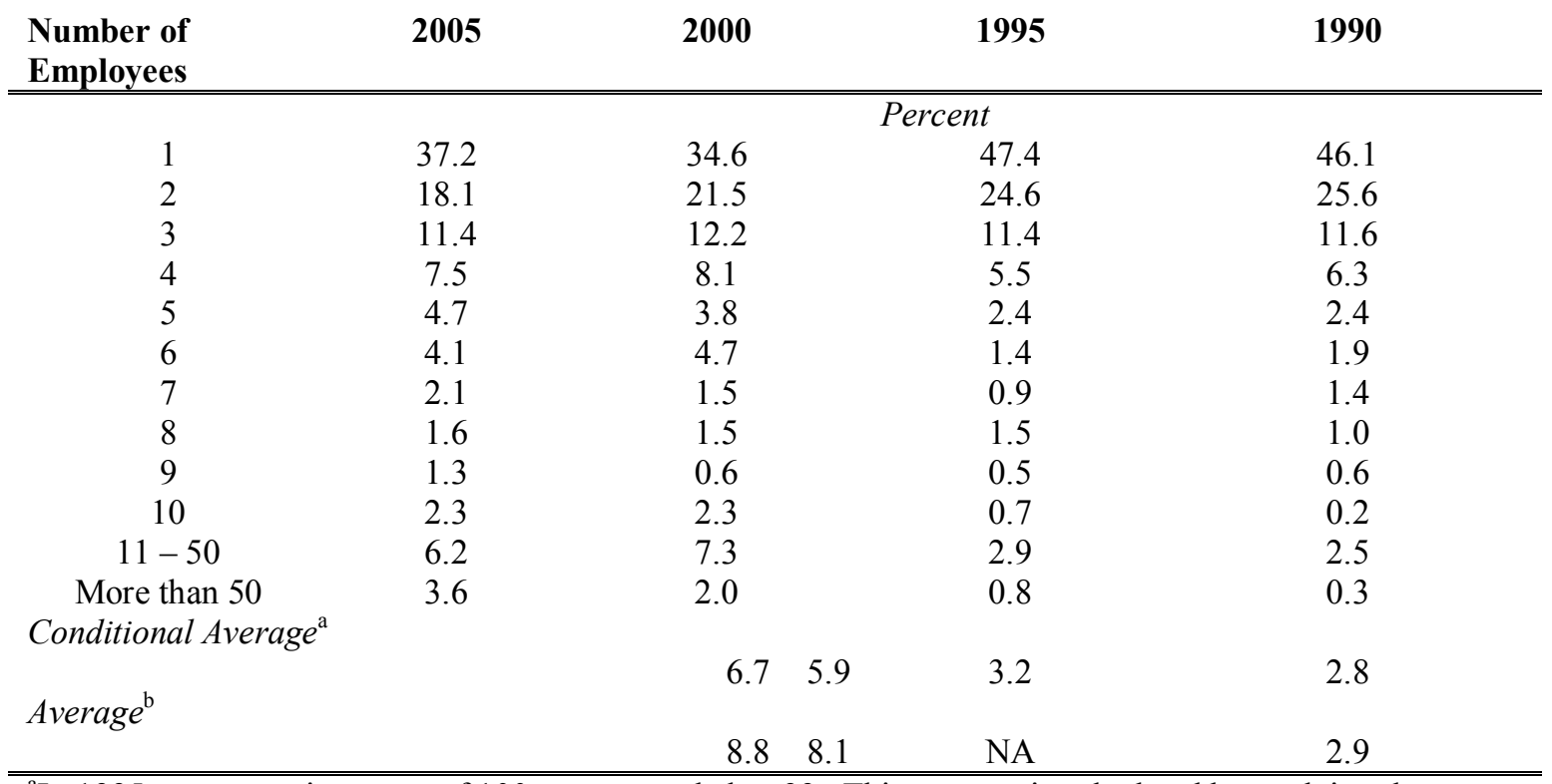

"In 1995, responses in excess of 100 were recorded as 99 . This average is calculated by applying the same condition to the 1990, 2000, and 2005 data. This makes the average comparable across all four surveys, but biases it downward.

${ }^{\mathrm{b}}$ This average is calculated without any restrictions on the maximum number of full-time employees reported by respondents. This makes the 1995 responses not applicable (NA), but the 1990, 2000, and 2005 averages are no longer biased.

Table 2: Base Salary Reported by Employees.

\begin{tabular}{|c|c|c|c|c|}
\hline Salary Range & 2005 & 2000 & 1995 & 1990 \\
\hline & \multicolumn{4}{|c|}{ Percent } \\
\hline$\$ 10,000$ or less & 5.9 & 3.3 & 6.3 & 14.1 \\
\hline$\$ 10,000-15,000$ & 3.1 & 3.5 & 6.6 & 17.8 \\
\hline$\$ 15,000-20,000$ & 3.3 & 8.4 & 17.5 & 23.8 \\
\hline$\$ 20,000-25,000$ & 11.5 & 18.9 & 26.8 & 22.6 \\
\hline$\$ 25,000-30,000$ & 16.9 & 21.5 & 19.9 & 10.6 \\
\hline$\$ 30,000-35,000$ & 16.7 & 15.8 & 9.6 & 5.4 \\
\hline$\$ 35,000-40,000$ & 12.4 & 13.2 & 6.1 & 2.1 \\
\hline$\$ 40,000+$ & 30.3 & 15.3 & 7.2 & 3.5 \\
\hline$\$ 40,000-50,000$ & 14.5 & 8.7 & 5.5 & NA \\
\hline$\$ 50,000-60,000$ & 6.5 & 2.6 & 1.7 & NA \\
\hline$\$ 60,000+$ & 9.3 & 4.0 & 0.0 & NA \\
\hline$\$ 60,000-75,000$ & 3.6 & NA & NA & NA \\
\hline$\$ 75,000+$ & 5.7 & NA & NA & NA \\
\hline
\end{tabular}

Note: NA means this response was not offered. 
Table 3: Difference in Wages by Selected Differences in Employees.

\begin{tabular}{|c|c|c|c|c|}
\hline & 2005 & 2000 & 1995 & 1990 \\
\hline Gender & \multicolumn{4}{|c|}{ Percent } \\
\hline Female vs. Male & -27.3 & -24.8 & -17.6 & -32.4 \\
\hline \multicolumn{5}{|l|}{ Education } \\
\hline High School Diploma vs. No High School Diploma & 9.9 & 15.0 & 19.0 & 24.5 \\
\hline 2-Year College Degree vs. High School Diploma & 12.5 & 12.4 & 8.9 & 10.2 \\
\hline 4-Year College Degree vs. 2-Year College Degree & 21.8 & 10.7 & 12.6 & 21.3 \\
\hline 4-Year College Degree vs. High School Diploma & 34.4 & 23.1 & 21.5 & 31.6 \\
\hline \multicolumn{5}{|l|}{ Experience and Tenure } \\
\hline One More Year of Experience vs. Average Experience & 1.9 & 1.0 & 1.7 & 2.3 \\
\hline One More Year of Tenure vs. Average Tenure & 0.8 & 0.2 & 0.4 & 0.8 \\
\hline \multicolumn{5}{|l|}{ Operation Size } \\
\hline 10 More Employees vs. Average Number of Employees & 0.3 & 1.2 & 2.1 & 2.5 \\
\hline \multicolumn{5}{|l|}{ Annual Hog Production } \\
\hline $1,000-2,000$ vs. Less than 1,000 & -3.5 & -17.3 & -0.4 & 16.1 \\
\hline $2,000-3,000$ vs. $1,000-2,000$ & -20.9 & -3.5 & 4.8 & 11.5 \\
\hline $3,000-5,000$ vs. $2,000-3,000$ & 13.4 & 6.6 & 9.4 & 4.6 \\
\hline $5,000-10,000$ vs. $3,000-5,000$ & -1.1 & 5.4 & 7.8 & 9.1 \\
\hline Over 10,000 vs. $5,000-10,000$ & 32.4 & 21.1 & 14.3 & 13.6 \\
\hline Over 10,000 vs. Less than 1,000 & 20.2 & 12.3 & 35.9 & 55.0 \\
\hline \multicolumn{5}{|l|}{ Region of Employment } \\
\hline Northeast vs. Midwest & 8.9 & -4.1 & 2.0 & 11.8 \\
\hline Southeast vs. Midwest & 2.6 & 7.2 & 7.5 & 4.9 \\
\hline West vs. Midwest & -8.9 & -4.6 & -1.2 & -0.3 \\
\hline
\end{tabular}


Table 4: Annual Wage Comparisons.

\begin{tabular}{|c|c|c|c|c|}
\hline & 2005 & 2000 & 1995 & 1990 \\
\hline Average for All Employees & $\$$ & 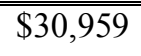 & $\$ 24,515$ & (\$19,847 \\
\hline \multicolumn{5}{|l|}{ Gender } \\
\hline Male & $\$ 36,712$ & $\$ 31,687$ & $\$ 24,796$ & $\$ 20,123$ \\
\hline Female & $\$ 28,364$ & $\$ 25,141$ & $\$ 21,630$ & $\$ 15,300$ \\
\hline \multicolumn{5}{|l|}{ Education } \\
\hline No High School Diploma & $\$ 26,679$ & $\$ 24,611$ & $\$ 18,197$ & $\$ 14,301$ \\
\hline High School Diploma & $\$ 30,727$ & $\$ 27,611$ & $\$ 22,948$ & $\$ 17,991$ \\
\hline 2-Year College Degree & $\$ 34,735$ & $\$ 31,070$ & $\$ 24,129$ & $\$ 19,105$ \\
\hline 4-Year College Degree & $\$ 42,279$ & $\$ 34,859$ & $\$ 27,486$ & $\$ 24,242$ \\
\hline \multicolumn{5}{|l|}{ Annual Hog Production } \\
\hline Under 1,000 & $\$ 32,639$ & $\$ 29,118$ & $\$ 19,622$ & $\$ 14,811$ \\
\hline 1,000 to 2,000 & $\$ 34,148$ & $\$ 23,320$ & $\$ 19,173$ & $\$ 17,078$ \\
\hline 2,000 to 3,000 & $\$ 24,612$ & $\$ 23,520$ & $\$ 19,891$ & $\$ 18,435$ \\
\hline 3,000 to 5,000 & $\$ 28,752$ & $\$ 24,541$ & $\$ 21,762$ & $\$ 19,328$ \\
\hline 5,000 to 10,000 & $\$ 26,608$ & $\$ 25,333$ & $\$ 23,070$ & $\$ 20,931$ \\
\hline Over 10,000 & $\$ 38,157$ & $\$ 33,227$ & $\$ 28,136$ & $\$ 26,124$ \\
\hline \multicolumn{5}{|l|}{ Region } \\
\hline Midwest & $\$ 35,516$ & $\$ 30,318$ & $\$ 23,465$ & $\$ 19,090$ \\
\hline Northeast & $\$ 34,589$ & $\$ 28,105$ & $\$ 23,233$ & $\$ 19,502$ \\
\hline Southeast & $\$ 39,787$ & $\$ 35,606$ & $\$ 28,449$ & $\$ 23,402$ \\
\hline West & $\$ 34,387$ & $\$ 31,454$ & $\$ 26,258$ & $\$ 21,385$ \\
\hline \multicolumn{5}{|l|}{ Title } \\
\hline Managers & $\$ 38,060$ & $\$ 32,277$ & $\$ 25,570$ & $\$ 20,983$ \\
\hline Assistant Managers & $\$ 33,115$ & $\$ 30,199$ & $\$ 23,105$ & $\$ 18,211$ \\
\hline Farrowing Managers & $\$ 30,780$ & $\$ 28,288$ & $\$ 23,621$ & $\$ 18,571$ \\
\hline Barn Worker/Herdsmen & $\$ 29,400$ & $\$ 27,781$ & $\$ 22,249$ & $\$ 17,570$ \\
\hline
\end{tabular}

Table 5: Incentives Offered to Employees.

Producer

Employee

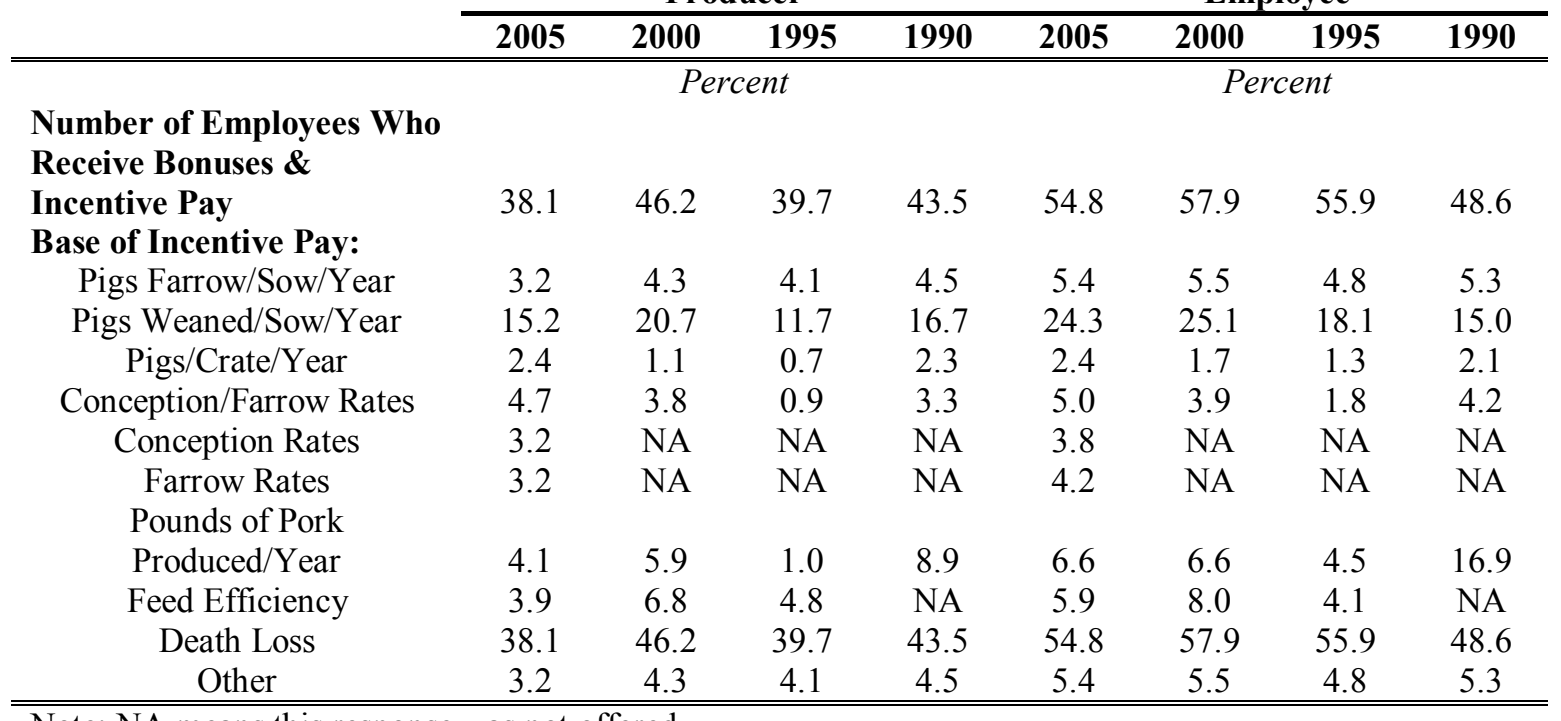

Note: NA means this response was not offered. 
Table 6: Employees Indicating the Availability of a Benefit.

\begin{tabular}{|c|c|c|c|c|}
\hline Benefit & 2005 & 2000 & 1995 & 1990 \\
\hline & \multicolumn{4}{|c|}{ Percent } \\
\hline Medical Insurance & 65.6 & 69.7 & 80.2 & 79.5 \\
\hline Dental Insurance & 36.3 & 35.0 & 46.7 & 47.7 \\
\hline Disability Insurance & 25.4 & 31.6 & 54.6 & 58.9 \\
\hline Life Insurance & 36.5 & 44.1 & 65.2 & 68.9 \\
\hline Paid Vacation & 71.8 & 85.5 & 78.3 & 68.2 \\
\hline Paid Holidays & 57.3 & 68.5 & 63.4 & 48.8 \\
\hline Workers' Compensation & 54.5 & 66.2 & 64.7 & 53.0 \\
\hline Unemployment Insurance & 33.8 & 35.9 & 34.3 & 25.0 \\
\hline Paid Sick Leave & 44.1 & 60.0 & 51.8 & 41.4 \\
\hline Pension/Retirement Plan & 54.1 & 49.7 & 35.7 & 47.2 \\
\hline Profit-sharing Plan & 18.2 & 24.4 & 18.4 & 27.1 \\
\hline Housing & 21.1 & 30.2 & 36.6 & 42.4 \\
\hline Paid Utilities & 14.6 & 16.8 & 21.9 & 27.6 \\
\hline Vehicle & 21.3 & 20.3 & 23.3 & 22.6 \\
\hline Processed Meat & 43.8 & 42.2 & 38.7 & 42.1 \\
\hline \multicolumn{5}{|l|}{ Continuing Education } \\
\hline (Tuition/Travel) & 19.9 & 23.0 & 26.2 & 20.7 \\
\hline Other & 6.4 & 10.4 & 8.3 & NA \\
\hline
\end{tabular}

Note: NA means this response was not offered. 
Iowa State University does not discriminate on the basis of race, color, age, religion, national origin, sexual orientation, gender identity, sex, marital status, disability, or status as a U.S. veteran. Inquiries can be directed to the Director of Equal Opportunity and Diversity, 3680 Beardshear Hall, (515) 294 - 7612 . 